\title{
Application of waste products from agricultural-food industry for production of rigid polyurethane-polyisocyanurate foams
}

\author{
Paciorek-Sadowska Joanna • Czupryński Bogusław • \\ Liszkowska Joanna
}

Published online: 18 September 2010

(c) The Author(s) 2010. This article is published with open access at Springerlink.com

\begin{abstract}
Solid parts of the wheat slops (90\% w/w of dry mass and $10 \% \mathrm{w} / \mathrm{w}$ of water) were applied as a filler (5-30\% w/w in relation to the sum of polyisocyanate and polyol masses) in PUR-PIR composition. Six foams containing different amounts of slops were prepared by this method and then, their physical-mechanical properties i.e. apparent density, compressive strength, brittleness, aftercombustion residue, stability of linear dimensions, change of volume, loss in mass ( $48 \mathrm{~h}$, temp $120^{\circ} \mathrm{C}$ ), softening point, content of the closed cells and absorbability of water were determined. Moreover, the foams were subjected to thermogravimetric and infrared analyses.
\end{abstract}

Keywords Rigid polyurethane-polyisocyanurate foams . Properties of foams - Wheat slops - Filler for foams

\section{Introduction}

The history of polyurethanes is relatively short but during about 70 years they became one of the most dynamically developed groups of polymers. They are applied practically in all the branches of polymer industry such as: foams, elastomers, thermoplastics, hardening plastics, adhesives, coatings, leak stoppers, fibres and so on $[1,2]$.

Polyurethanes are used almost in each branch of industry and they contribute to the change of human life quality. Furniture, mattresses, car seats, shoe soles, thermal insulation for refrigerators and buildings, imitation wood, packages or coatings are only some examples of

P.-S. Joanna $(\bowtie) \cdot C$. Bogusław · L. Joanna

Chair of Chemistry and Technology of Polyurethanes, Casmir the Great University, Bydgoszcz, Poland

e-mail: sadowska@ukw.edu.pl polyurethane applications in everyday life. The substantial part of them is manufactured in a form of rigid polyurethane foams.

In order to reduce the costs of production of the rigid polyurathane foams and simultaneously to improve some of their physical-mechanical properties, the different fillers are applied for their preparation [3-6].

The distillery slops are by-products obtained in agricultural distilleries and the management of its total amount cause difficulties. That is why the utilization of the mentioned by-product aroused scientists' interest for a long time [7, 8].

The aim of the paper is study on utilization of the solid fraction of the wheat slops for preparation of rigid polyurethane-polyisocyanurate (PUR-PIR) foams. The wheat slops are applied as a filler in order to reduce the costs of foam production and simultaneously to improve some physical-mechanical properties of foams.

\section{Experimental}

\subsection{Preparation of wheat slops for production of rigid PUR-PIR foams}

Solid fraction of wheat slops obtained in agricultural distillery (Cargil, Bielany Wrocławskie, Poland) was applied in our studies. Wheat slops were obtained by fermentation of the wheat starch milk (17.1\% of starch, $16.2 \%$ of dry mass). The slops dry mass consisted of raw fat $(9.87 \%$, PN-ISO 6492:2005), raw fibre (4.07\%, PN-EN ISO 6865:2002(U)), proteins (24.99\%, PN-92/R-64811) and mineral compounds $(3.92 \%)$. Chemical composition of mineral compounds in wheat slops was as follows: phosphorus $(0.84 \%, \mathrm{PN}-\mathrm{ISO}$ 6491:2000), sodium (1.04\%, PN-R-64782:1994) and 
chlorine (0.63\%, PN-93/R-64750). Solid fraction was separated from water on Büchner funnel, dried in blast drier at temperature of $100{ }^{\circ} \mathrm{C}$ and then, it was grinded in a ball mill. The obtained solid contained humidity of $6.7 \%$ (balancedrier, PN-76/R-64752) and its colour was brown. In order to obtain rigid PUR-PIR foams, the solid fraction with grain dimensions of $1 \mathrm{~mm}$ was used (sieve analysis, PN-71/C04501).

\subsection{Preparation of rigid PUR-PIR foams}

The rigid PUR-PIR foams were obtained in a laboratory scale by one-stage method from the two-component $(\mathrm{A}+\mathrm{B})$ system at the equivalent proportion of $\mathrm{NCO}$ to $\mathrm{OH}$ groups equal since $3: 1-3: 2.2$. The component $\mathrm{A}$ was composed from polyol, catalysts, a surface active agent, flame retardant, porophor and solid fraction of wheat slops added in amount within the range from 5 to $30 \% \mathrm{w} / \mathrm{w}$. The component B was polyisocyanate (Table 1). Both components were mixed $(1,800 \mathrm{rpm})$ at respective weight ratios and poured onto an open rectangular tray. After foaming, the foams were thermostated for $4 \mathrm{~h}$ at the temperature of $120{ }^{\circ} \mathrm{C}$; then the foams were seasoned for $48 \mathrm{~h}$ at the temperature of $20 \pm 4{ }^{\circ} \mathrm{C}$. In that manner, one standard foam (no. W0) without filler and six foams containing solid fraction of wheat slops as a filler (nos. W1-W6) were prepared. After seasoning, the foams were cut and their fundamental properties were determined according to the obligatory standards (Table 2). Each type of the system prepared was subjected to four times control foaming.
2.3 Directions of studies on the properties of rigid PUR-PIR foams

Polyurethanes are segment polymers consisting of the rigid and flexible segments. The rigid segments have an effect on mechanical and thermal strength, high elasticity module, whereas, the elastic ones influence softness, flexibility, high values of ultimate elongation and resistance at low temperature. It was noticed that there is a close dependence between properties of polyurethanes and their physical and chemical structures.

Directions of studies on properties of rigid polyurethane foams are determined by their physical (density, water absorptivity, flammability), mechanical (compressive strength, brittleness), electrical (heat conduction) and chemical (ageing, content of closed cells) properties.

An apparent density of the foams tested was determined by the use of the cubical samples (side of $50 \mathrm{~mm}$, ISO 8451988 standard) and it was expressed as a ratio of foam mass to its geometric volume. Prior to cutting-out the samples used for the determination of apparent density, the foams were seasoning for $24 \mathrm{~h}$ at room temperature. Then, the samples were cut-out accurate to $0.1 \mathrm{~mm}$ and weighted accurate to $0.1 \mathrm{~g}$.

Determination of water absorptivity was carried out according to DIN 53433 standard. The method consisted in measurement of the buoyant force of a sample $(150 \times$ $150 \times 25 \mathrm{~mm}$ ) immersed in distilled water for $24 \mathrm{~h}$. The method is applied for all rigid porous plastics which do not react with water and are insoluble in water. Water absorbability is a ratio of the absorbed water volume to the initial sample volume expressed in percentage.

Table 1 Composition of the reaction mixtures applied for the rigid PUR-PIR foams preparations

\begin{tabular}{|c|c|c|c|c|c|c|c|c|c|}
\hline \multirow[t]{2}{*}{ Materials } & \multirow[t]{2}{*}{ Characteristics (manufacturer) } & \multicolumn{8}{|c|}{ Symbol of foam } \\
\hline & & Unit & W0 & W1 & W2 & W3 & W4 & W5 & W6 \\
\hline Rokopol RF-55 & $\begin{array}{l}\text { Product of oxypropylation of sorbitol } \mathrm{L}_{\mathrm{OH}}=495 \\
\text { mgKOH/g (Alfasystems, Brzeg Dolny, Poland) }\end{array}$ & $\mathrm{g}$ & 60.0 & 60.0 & 60.0 & 60.0 & 60.0 & 60.0 & 60.0 \\
\hline Silicon L6900 & $\begin{array}{l}\text { Polysiloxypolyalkyleneoxydimethylene copolymer } \\
\text { (Witco, Sweden) }\end{array}$ & $\mathrm{g}$ & 5.2 & 5.2 & 5.2 & 5.2 & 5.2 & 5.2 & 5.2 \\
\hline DABCO 33LV & $\begin{array}{l}33 \% \text { solution of triethylenediamine }[1,4- \\
\text { diazobicyclo }(2,2,2) \text { octane] in dipropylene glycol, } \\
\text { applied to foams (Germany) }\end{array}$ & $\mathrm{g}$ & 3.1 & 3.1 & 3.1 & 3.1 & 3.1 & 3.1 & 3.1 \\
\hline Catalyst 12 & $\begin{array}{l}33 \% \text { potassium acetate in diethylene glycol applied } \\
\text { to foams (KChiTP, UKW, Bydgoszcz, Poland) }\end{array}$ & $\mathrm{g}$ & 7.2 & 7.2 & 7.2 & 7.2 & 7.2 & 7.2 & 7.2 \\
\hline AntiblazeTMCP & $\begin{array}{l}\text { Flame retardant, tri(2-chloro-1-methylene-ethylene) } \\
\text { phosphate (Albright and Wilson, Great Britain) }\end{array}$ & $\mathrm{g}$ & 51.6 & 51.6 & 51.6 & 51.6 & 51.6 & 51.6 & 51.6 \\
\hline \multirow{2}{*}{$\begin{array}{l}\text { Solid fraction } \\
\text { of wheat slops }\end{array}$} & \multirow[t]{3}{*}{ Cargill firm (Poland) } & $\mathrm{g}$ & 0 & 17.2 & 34.4 & 51.6 & 68.8 & 86.0 & 103.2 \\
\hline & & $\%$ & 0 & 5.0 & 10.0 & 15.0 & 20.0 & 25.0 & 30.0 \\
\hline Distilled water & & $\mathrm{g}$ & 3.8 & 3.8 & 3.8 & 3.8 & 3.8 & 3.8 & 3.8 \\
\hline Ongromat $20-30$ & Polyisocyanate NCO groups, $31 \%$ & $\mathrm{~g}$ & 284.0 & 284.0 & 284.0 & 284.0 & 284.0 & 284.0 & 284.0 \\
\hline
\end{tabular}


Table 2 Parameters of processing and density of PURPIR foams prepared

\begin{tabular}{lllll}
\hline $\begin{array}{l}\text { Symbol } \\
\text { of foam }\end{array}$ & $\begin{array}{l}\text { Start } \\
\text { time }(\mathrm{s})\end{array}$ & $\begin{array}{l}\text { Time of } \\
\text { expanding }(\mathrm{s})\end{array}$ & $\begin{array}{l}\text { Time of } \\
\text { gelation (s) }\end{array}$ & $\begin{array}{l}\text { Density (ISO 845-1988) } \\
\left(\mathrm{kg} / \mathrm{m}^{2}\right)\end{array}$ \\
\hline W0 & 15 & 16 & 35 & 36.6 \\
W1 & 16 & 18 & 39 & 33.2 \\
W2 & 19 & 24 & 40 & 31.5 \\
W3 & 25 & 30 & 48 & 28.0 \\
W4 & 29 & 38 & 57 & 27.9 \\
W5 & 34 & 42 & 66 & 26.8 \\
W6 & 38 & 49 & 75 & 25.6 \\
\hline
\end{tabular}

The flammability of the obtained PUR-PIR foams was tested by three methods:

1. According to PN-78 C-05012 standard-horizontal test. The method consisted in determination of velocity of the flame superficial propagation along the sample $(150 \times 50 \times 13 \mathrm{~mm})$ placed horizontally and kindled at one end. The velocity of the flame superficial propagation is defined as the velocity of the flame front shifting along the surface of the flammable material tested.

The tested foam sample was placed on a horizontally fixed net and then the burner with a flame was put to one of the ends for $60 \mathrm{~s}$. A transverse line was marked in the distance of $125 \mathrm{~mm}$ from the sample end to which the burner was applied. The distance of the flame front shifting and the time necessary to reach the marked transverse line by the front of flame were measured. If the ignited foam goes out before flame reaches a control mark, the foam is defined as the self-extinguishing one. The ability of foam to self-extinguishing can also be evaluated by measurement of the length of the burned segment. In the case when foam is not extinguished, we can determine the mean time of burning of the tested segment or velocity of flame propagation (in $\mathrm{mm} / \mathrm{s}$ ) on the basis of distance traversed by the front of flame in the defined time.

2. According to ASTM D3014-73 standard-simplified chimney test-(Butler's vertical test). Apparatus used to determine the flammability according to the vertical test consisted of a vertical column $(300 \times 57 \times 54 \mathrm{~mm})$ whose three walls were made from metal plate and the fourth one was a movable pane. Six foam samples $(150 \times 19 \times 19 \mathrm{~mm})$ were tested. Before burning, the samples were weighted accurate to $0.0001 \mathrm{~g}$ and then they were placed inside a chimney. A pane was installed and a flame from the burner, supplied with a gas: propanebutane, was brought into contact with the sample for $10 \mathrm{~s}$. Then, the burner was removed and the time of the sample free burning and retention (residue after burning) were measured by stopwatch in vertical test. Retention was calculated from Eq. 1:

$R_{e}=\frac{m}{m_{0}} \times 100 \%$ where $R_{e}$ is the retention, $m_{O}$ is the mass of sample before burning ( $\mathrm{g}$ ) and $m$ is the mass of sample after burning $(\mathrm{g})$.

3. Conical calorimeter-by the use of experimental method described in ISO 5660-1:2001 standard

Basic research tool in this method is the conical calorimeter. The test consists in subjecting the impact of thermal radiation on standard samples measuring $100 \times 100 \mathrm{~mm}$. During the experiments, time required to initiate the reaction of combustion and thermokinetic parameter i.e. rate of heat release, total amount of heat released, selected toxic and fume-forming properties were recorded (see: Table 2). Thermokinetic quantities were determined on the basis of calorimetry theory of oxygen consumption. It says that about $13.1 \mathrm{~kJ}$ of heat is released for each $1 \mathrm{~g}$ of oxygen consumed (accurate to $\pm 5 \%$ ). Studies were carried out for samples of materials laid horizontally and reaction of combustion was initiated by ignition. Samples of materials were subjected to the action of heat radiation at intensity of $30 \mathrm{~kW} / \mathrm{m}^{2}$. Test was finished when the flame combustion declined.

Compressive strength was determined by the use of general-purpose strength machine (Instron 5544). The peel and flanks of foam were cut off and the cubic samples were cut-out (side of $50 \pm 1 \mathrm{~mm}$ ). Then, the samples were subjected to compressive strain by $10 \%$ according to direction of foam expansion.

Brittleness of foams was determined using standard apparatus according to ASTM C-421-61 standard. It was calculated as a loss in mass (in percents) of 12 foam cubes (side of $25 \mathrm{~mm}$ ) in relation to their initial mass. Apparatus applied to determine the brittleness of PUR foams was a cubical box $(190 \times 197 \times 197 \mathrm{~mm})$ made from an oaken wood and rotating about an axis with a speed of $60 \mathrm{rpm}$. The box was filled with 24 oak cubes $(20 \times 20 \times 20 \mathrm{~mm})$.

The loss in foam mass (\%) i.e. measure of its brittleness is expressed by Eq. 2:

$K=\frac{m_{1}-m_{2}}{m_{1}} \times 100 \%$

where $m_{1}$ is the mass of shaped foam before test and $m_{2}$ is the mass of shaped foam after test. 
Softening point (as a thermal resistance under compressive stress) was determined by the use of cubical samples (side of $20 \mathrm{~mm}$ ), longwise the direction of foam expansion, in accordance with DIN 53424 standard. The foam samples were subjected to the action of compressive load of $24.52 \mathrm{kPa}$ per hour at temperature of $50{ }^{\circ} \mathrm{C}$. Temperature at which the sample was compressed by $2 \mathrm{~mm}$ was accepted as the softening point.

Thermal resistance of foams was determined under dynamic conditions in air atmosphere at the heating rate of $5 \mathrm{deg} / \mathrm{min}$ within the range of temperature from 20 to $800{ }^{\circ} \mathrm{C}$. Tests were carried out using derivatograph produced by MOM Budapest (Paulik-Paulik-Erdey).

Heat conductivity of foams was defined by determination of the thermal conductance $\lambda$. The dimensions of the foam samples were: $200 \times 200 \times 25 \mathrm{~mm}$ and the apparatus "FOX 200" (Lasercomp) was used for testing. It allowed us to determine $\lambda$ value within the range from 20 to $100 \mathrm{~mW} /(\mathrm{m} \cdot \mathrm{K})$. The method consists in the determination of quantity of heat flowing through the given material in the time unit during steady heat flow at constant temperature difference on opposite sides of sample.

Change in the linear dimensions of foams were determined after $48 \mathrm{~h}$ of thermostating at temperature of $120{ }^{\circ} \mathrm{C}$ (393 K) by using the cubical samples (side of $50 \mathrm{~mm}$ ). Samples of foams were measured longwise the direction of the foam expansion. Change in linear dimensions was calculated from Eq. 3:

$\Delta l=\frac{l-l_{0}}{l_{0}} \times 100 \%$

where $l_{0}$ is the length of sample before thermostating $(\mathrm{mm})$ and $l$ is the length of sample after thermostating $(\mathrm{mm})$.

The loss in mass of foams was determined after $48 \mathrm{~h}$ of thermostating at temperature of $120^{\circ} \mathrm{C}(393 \mathrm{~K})$ by using the cubical samples (side of $50 \mathrm{~mm}$ ). The loss in mass of foams was calculated from Eq. 4:

$\Delta m=\frac{m_{0}-m}{m_{0}} \times 100 \%$

where $m_{0}$ is the mass of sample before thermostating $(\mathrm{g})$ and $m$ is the mass of sample after thermostating $(\mathrm{g})$.

Changes in volume of the foams were determined after $48 \mathrm{~h}$ of thermostating at temperature of $120{ }^{\circ} \mathrm{C}(393 \mathrm{~K})$ by using the cubical samples (side of $50 \mathrm{~mm}$ ). Samples were measured longwise the direction of the foam expansion. Change in volume was calculated from Eq. 5:

$\Delta V=\frac{V-V_{0}}{V_{0}} \times 100 \%$

where $V_{0}$ is the volume of sample before thermostating and $V$ is the volume of sample after thermostating.
Content of the closed cells was determined in accordance to PN-ISO 4590:1994 standard by method II (dimensions of samples: $100 \times 30 \times 30 \mathrm{~mm}$ ). The method consisted in determination of the relative pressure drop (earlier calibrated for the volume standards) from the differences in indications on the scale of manometer whose one arm was opened to atmosphere. The method is appropriate for the determination of closed cells content in rigid porous plastics expressed in percentage. The polyurethane-polyisocyanurate foams were analyzed by FTIR spectroscopy ( $\mathrm{KBr}$ technique, a Vector spectrometer, Brucker, range from 400 to $4,000 \mathrm{~cm}^{-1}$ ).

\section{Results and discussion}

Compositions of the prepared polyurethane-polyisocyanurate foams are presented in Table 1.

During synthesis of polyurethane-polyisocyanurate foams, process of the reaction mixture foaming was monitored by measurements of the respective technological times: start time, time of expansion and time of gelation. The different times of loss in stickiness of the expanded foam can be observed. It depends on the kind of medium (air, wall of the mould), which is in contact with surface layer of the expanded foam. It was found that the most rapid loss in stickiness was in the case of foam surface being in contact with air. Until now, more objective methods for the determination of phenomena during expanding of polyurethane foam have not been described. Additionally, density of the new rigid foams was determined. The results are presented in Table 2.

Rigid foams prepared with addition of solid fraction of wheat slops were characterized by the longer times of processing. Start time was within the range from $16 \mathrm{~s}$ for standard foam to $38 \mathrm{~s}$ for foam containing $30 \% \mathrm{w} / \mathrm{w}$ of filler, time of expansion was from $18 \mathrm{~s}$ for standard foam to $49 \mathrm{~s}$ for foam containing $30 \% \mathrm{w} / \mathrm{w}$ of filler and times of gelation did not exceed $75 \mathrm{~s}$ for all foams.

During foaming process, lasting from several to dozens seconds, many phenomena determined by a kind of raw materials occur and they decide about functional properties of the foams. As a result of changes in recipe for production of rigid PUR-PIR foams, the porous plastics characterized by varied apparent densities were obtained. Increase in amount of solid fraction of wheat slops in foam composition from 5 to $30 \% \mathrm{w} / \mathrm{w}$ in relation to the sum of polyol and polyisocyanate masses resulted in a distinct decrease of the foam apparent density from $36.96 \mathrm{~kg} / \mathrm{m}^{3}$ for standard foam to $25.6 \mathrm{~kg} / \mathrm{m}^{3}$ for foam containing the highest amount of slops $(30 \%)$. The structure of polyurethane matrix has a fundamental effect on mechanical properties and durability of foam. By changes made in recipe for preparation of 
foams, we can influence some properties of final product. However, the apparent density and cell structure are of the greatest importance for creation of mechanical properties of PUR foams. Results of mechanical determinations of PUR-PIR foams prepared are presented in Table 3.

Studies on mechanical properties of PUR-PIR foams allow us to state that the solid fraction of wheat slops play an important role in formation of these properties. Compressive strength of foams measured in perpendicular direction considerably reduction after application of the slops (Fig. 1).

As the content of slops was increased in foam composition from 5 to $30 \%$ w/w (foams W1-W6), the compressive strength determined in direction of foam expansion was reduced from $221.7 \mathrm{kPa}$ (standard foam) to $79.0 \mathrm{kPa}$ (foam no. W7, $30 \% \mathrm{w} / \mathrm{w}$ of slops). It is obvious since changes in mechanical strength of foams are strictly related to their apparent density.

Also brittleness of foams is connected with their density. Application of wheat slops for preparation of the rigid PUR-PIR foams resulted in considerable reduction of their brittleness. The distinct reduction in foam brittleness was observed as the content of wheat slops was increased in foam composition from $41.9 \%$ (standard foam) to $16.9 \%$ (foam containing 30\% w/w of solid fraction of wheat slops), Fig. 2. However, softening point only slightly decreased from $230{ }^{\circ} \mathrm{C}$ (standard foam) to $221{ }^{\circ} \mathrm{C}$ (foam no. W6). In order to check a behaviour of the new foams in flame, the different tests were performed. The oxygen index i.e. percentage of oxygen content in the mixture with nitrogen, which maintains burning of sample was determined. Another method for the determination of flammability, flame maintenance by material and many other parameters characterizing process of combustion is the method of conical calorimetry. The conical calorimeter is the most important method applied in industry for testing the flammability of polymers. The next method applied for the determination of polymer flammability is Butler's test

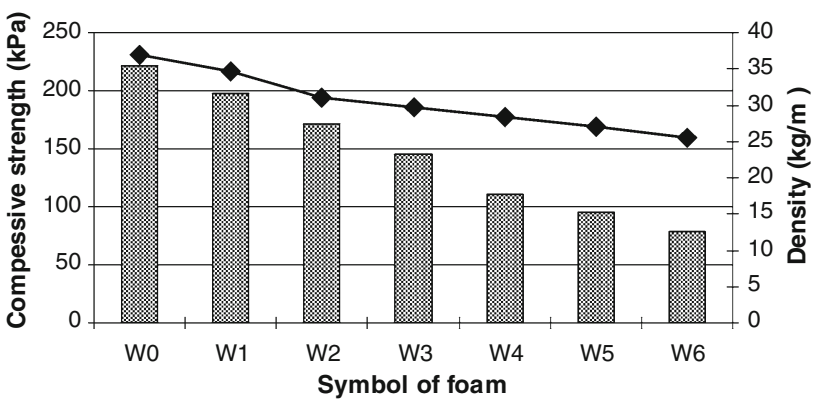

Fig. 1 Dependence between compressive strength and density of the rigid PUR-PIR foams obtained

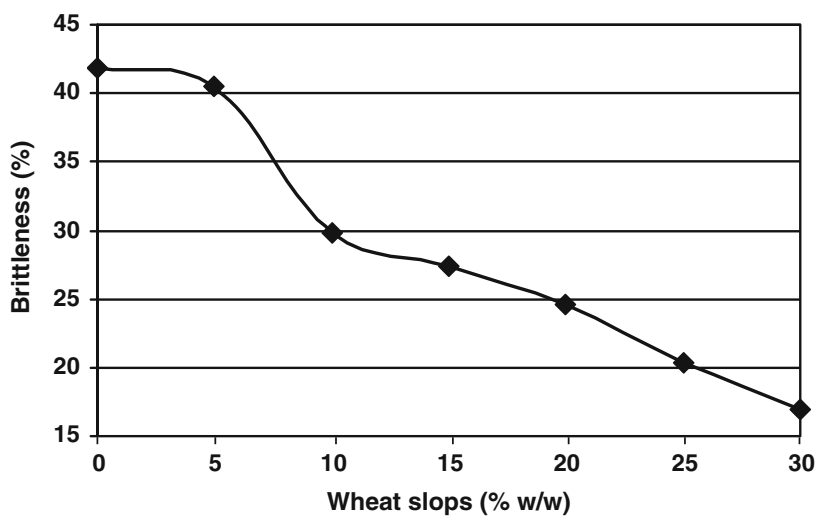

Fig. 2 Dependence between brittleness of rigid PUR-PIR foams and content of solid fraction of wheat slops

(so called vertical test). The test consists in burning of foam sample and then, retention (residue after burning) is calculated according to the formula given in the standard.

Comparison of the basic combustion parameters of the foams (standard and with of tri wheat slops on the basis of combustion tests is presented in Table 4.

Foams with addition of the wheat slops (W1-W6) are characterized by longer time to durable ignition (4 and $6 \mathrm{~s}$, respectively) than the standard foam ( $3 \mathrm{~s})$, what is

Table 3 Fundamental functianol properties of the rigid PUR-PIR foams

\begin{tabular}{|c|c|c|c|c|c|c|c|}
\hline \multirow[t]{2}{*}{ Characteristics } & \multicolumn{7}{|c|}{ Symbol of foam } \\
\hline & W0 & W1 & W2 & W3 & W4 & W5 & W6 \\
\hline Compressive strength in direction of foam expansion (ISO 844:1993), $\mathrm{kPa}$ & 221.7 & 192.3 & 160.5 & 144.3 & 106.1 & 92.6 & 79.0 \\
\hline Brittleness (ASTM C-421-61), \% & 41.9 & 40.5 & 29.8 & 27.4 & 24.6 & 20.4 & 16.9 \\
\hline Retention (ASTM D3014-73) & 76.6 & 69.7 & 61.2 & 52.6 & 44.7 & 39.2 & 31.9 \\
\hline Softening point (DIN 53424 ), ${ }^{\circ} \mathrm{C}$ & 230 & 230 & 227 & 225 & 221 & 223 & 221 \\
\hline Content of closed cells (PN-ISO 4590:1994) & 83.4 & 88.9 & 85.3 & 81.7 & 76.5 & 69.3 & 64.7 \\
\hline Loss in mass after $48 \mathrm{~h}$ of thermostating at $120^{\circ} \mathrm{C}, \%$ & 1.1 & 1.1 & 1.2 & 1.2 & 1.2 & 1.3 & 1.3 \\
\hline Change in linear dimensions after $48 \mathrm{~h}$ of thermostating at $120{ }^{\circ} \mathrm{C}, \%$ & -0.1 & -0.6 & -0.6 & -0.8 & -0.8 & -0.8 & -0.8 \\
\hline Change in volume after $48 \mathrm{~h}$ of thermostating at $20^{\circ} \mathrm{C}, \%$ & -0.5 & -1.0 & -1.0 & $-1,2$ & -1.2 & -1.2 & -1.2 \\
\hline Absorbability of water DIN 53433 & 1.8 & 2.03 & 2.1 & 2.5 & 2.9 & 3.3 & 3.5 \\
\hline
\end{tabular}


Table 4 Results of flammability tests for rigid PUR-PIR foams

\begin{tabular}{|c|c|c|c|c|c|c|c|}
\hline Characteristics & W0 & W1 & W2 & W3 & W4 & W5 & W6 \\
\hline Retention (ASTM D3014-73), \% & 67.3 & 67.9 & 68.7 & 69.5 & 70.3 & 71.3 & 72.4 \\
\hline Time of ignition, (ISO 5660-1:2001), s & 3 & 4 & 4 & 5 & 5 & 5 & 6 \\
\hline Intensity of fume emission, ((ISO 5660-1:2001), $\mathrm{m}^{2} / \mathrm{m}^{2}$ & 200.5 & 116.1 & 116.2 & 115.8 & 115.4 & 115.2 & 115.3 \\
\hline Mean proper emission of CO, (ISO 5660-1:2001), g/g & 0.147 & 0.104 & 0.100 & 0,987 & 0.980 & 0.978 & 0.970 \\
\hline Mean proper emission of $\mathrm{CO}_{2}$, (ISO 5660-1:2001), g/g & 1.87 & 1.02 & 1.11 & 1.10 & 1.04 & 1.02 & 1.01 \\
\hline Total amount of heat emitted, (ISO 5660-1:2001), MJ $/ \mathrm{m}^{2}$ & 10.7 & 6.5 & 6.5 & 6.5 & 6.4 & 6.3 & 6.3 \\
\hline Oxygen index, (ISO 3216), \% & 19.6 & 19.8 & 19,8 & 20.0 & 20.2 & 20.3 & 20.5 \\
\hline
\end{tabular}

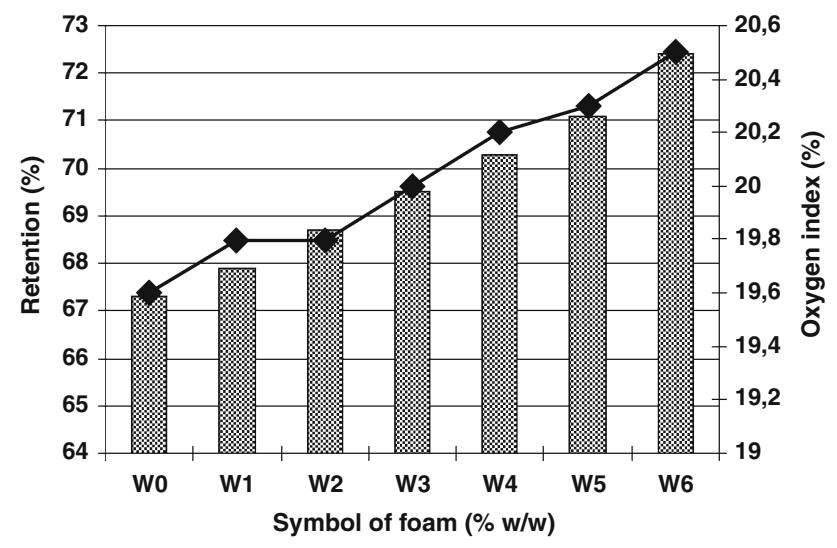

Fig. 3 Increase in retention and oxygen index of PUR-PIR foam

consistent with results of oxygen index determination. Oxygen index for standard foam is $19.6 \%$ and for foams containing of wheat slops, it is 19.8 (W1 foam) and 20.5 (W6 foam). On the basis of oxygen index determination, it was found that presence of the wheat slops in PUR-PIR foam composition resulted in flammability reduction by about $2 \%$. The values of total heat emission during combustion show that the wheat slops demonstrates cooling properties. Tests in conical calorimeter showed that foams prepared with wheat slops formed carbonized residue in a smaller degree. The foams containing wheat slops also are characterized by higher retention (residue after combustion). Retention of standard (foam W0) was $67.3-72.4 \%$ (foam W6) (Fig. 3).

On the basis of experiments carried out under conditions corresponding to the I-st phase of fire expansion, it was found that thermokinetical properties were very similar. The differences between the results obtained were not higher than 5-7\%. Analysis of smoke-producing properties showed that the samples marked W0 and W1 were characterized by the highest intensity of smoking while samples W5 and W6 by the lowest one. The highest mean emission of CO was in the case of sample W0. Similar characteristics was observed for maximum specific emission. The results show that this value is considerably higher (over twice) in comparison with other materials. Similar dependence can be formulated for $\mathrm{CO}_{2}$.

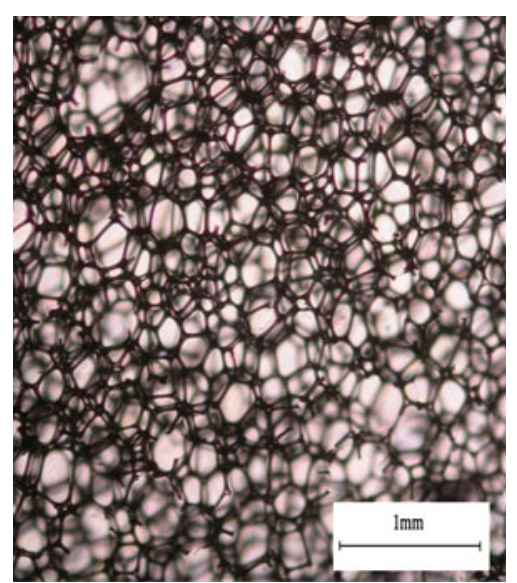

Fig. 4 Cellular structure of W0 foam

Stability of linear dimension, volume and loss in mass was tested after $48 \mathrm{~h}$ of thermostating at temperature of $120{ }^{\circ} \mathrm{C}$. Time of thermostating was $48 \mathrm{~h}$, since the most characteristic changes in mass occur in polyurethane foam during the first $24-72 \mathrm{~h}$ of their ageing. On the basis of ageing test results, it was found that there was a strict dependence between stability of dimensions, loss in mass and change in volume of foams and the wheat slops. Generally, materials foamed by carbon dioxide are characterized by variable stability in linear dimensions (tendency to shrinkage). Change of linear dimensions was determined only in direction of the foam expansion.

Photographs of cellular structure of the foams prepared show the effect of solid fraction of wheat slops on size and shape of cells (Figs. 4 and 5).

Standard foam (W0) is characterized by the small irregular cells slightly elongated in the direction of growth. However, application of filler in the form of slops in PURPIR foam allowed us to obtain larger and more regularly packed cells. Structure of foam cells with wheat slops explains their lower density and consequently, lower compressive strength.

Rigid polyurethane foams are widely applied as thermoinsulating materials and from among all the materials available on market, they are the best ones. Perfect thermoinsulating properties of PUR foams result from their 


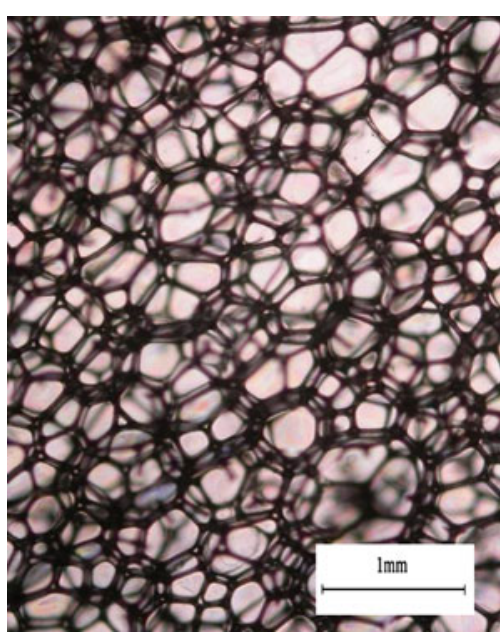

Fig. 5 Cellular structure of W6 foam

low thermal conductivity and suitable cellular structure. That is why, determination of parameters affecting these properties is very important. Thermal conductivity for all the foams, both standard foam and foams modified with a filler in the form of solid parts of wheat slops, was practically similar i.e. about $30.7 \mathrm{~mW} / \mathrm{mK}$.

Rigid polyurethane-polyisocyanurate foams are cellular material with clear numerical superiority of closed cells and participation of open pores is within the limit from about 5 to $10 \%$. Gas closed in foam cells and also, but to a lesser extend, structure of polyurethane matrix participate in the heat flow. The wheat slops applied to produce rigid PUR-PIR foams caused slight decrease in amount of closed cells in comparison with standard foam. Content of closed cells in standard foam was $83 \%$. The highest amount of closed cells was observed for foam W1-81\%, an slightly lower for foam W6-78\%.
In order to obtain full characteristics of thermal resistance, all prepared foams were subjected to thermogravimetric analysis under dynamic conditions at air atmosphere, at heat rate $5{ }^{\circ} \mathrm{C} / \mathrm{min}$, within the range of temperatures from 20 to $800{ }^{\circ} \mathrm{C}$. On the ground of TG (change in mass) and DTG curves (derivative of change in mass), the characteristics were determined as follows: temperature $\left({ }^{\circ} \mathrm{C}\right)$ of the first change in sample mass, extrapolated temperature $\left({ }^{\circ} \mathrm{C}\right)$ of the main loss in mass and temperature $\left({ }^{\circ} \mathrm{C}\right)$ of the highest rate of loss in mass (extreme on DTG curve). Thermogram of PUR-PIR foam containing solid fraction of wheat slops is presented in Fig. 6.

Analysis in air atmosphere showed two-stage process of foam degradation. The first loss in mass for the foams prepared was at temperature from $164^{\circ} \mathrm{C}$ for standard foam to $180{ }^{\circ} \mathrm{C}$ for (W0) foam and $208{ }^{\circ} \mathrm{C}$ for (W6) foam. The first loss in foam mass is caused by diffusion of carbon dioxide which plays the role of porophor in the foams studied. Carbon dioxide is formed as a result of reaction of the excess of isocyanurate groups (-NCO) with water. Within the range of temperature from 85 to $110{ }^{\circ} \mathrm{C}$, diffusion of triethylenediamine from foams can also occur. Triethylenediamine (DABCO) in the form of 33\% solution in dipropylene glycol is applied as a catalyst of polyisocyanates reaction with polyol. Extrapolated beginning of the main loss in mass occurred at temperature from $181{ }^{\circ} \mathrm{C}$ for standard foam to $229^{\circ} \mathrm{C}$ for W6 foam. Extrapolated temperature of the main loss in mass of standard foam is connected, among others, with decomposition of urea formed in reaction of polyisocyanate with water and urethane groups. Whereas, the highest rate of loss in mass was observed at temperature from $289^{\circ} \mathrm{C}$ for standard foam to $314{ }^{\circ} \mathrm{C}$ for W6 foam. The degradation curves of the foams obtained were compared and it was found that loss in mass
Fig. 6 Thermogram of PURPIR foam containing solid fraction of wheat slops

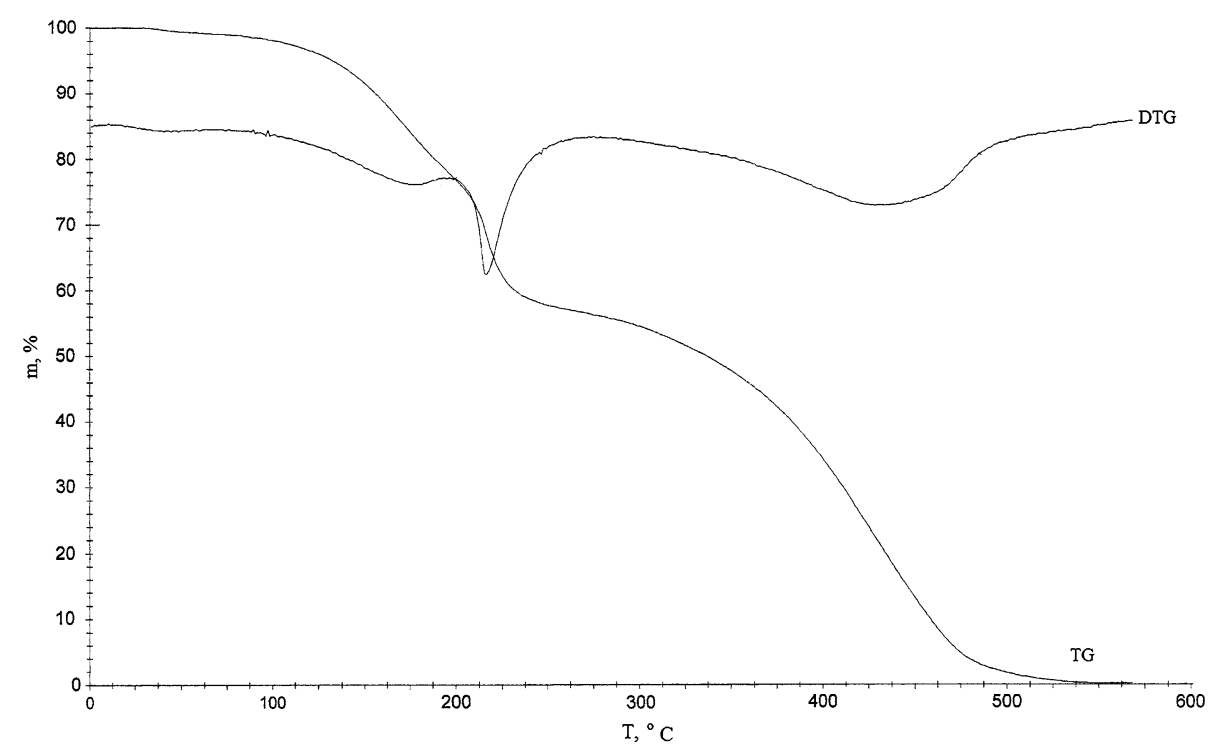


Fig. 7 IR spectrum of PURPIR foam containing solid fraction of wheat slops

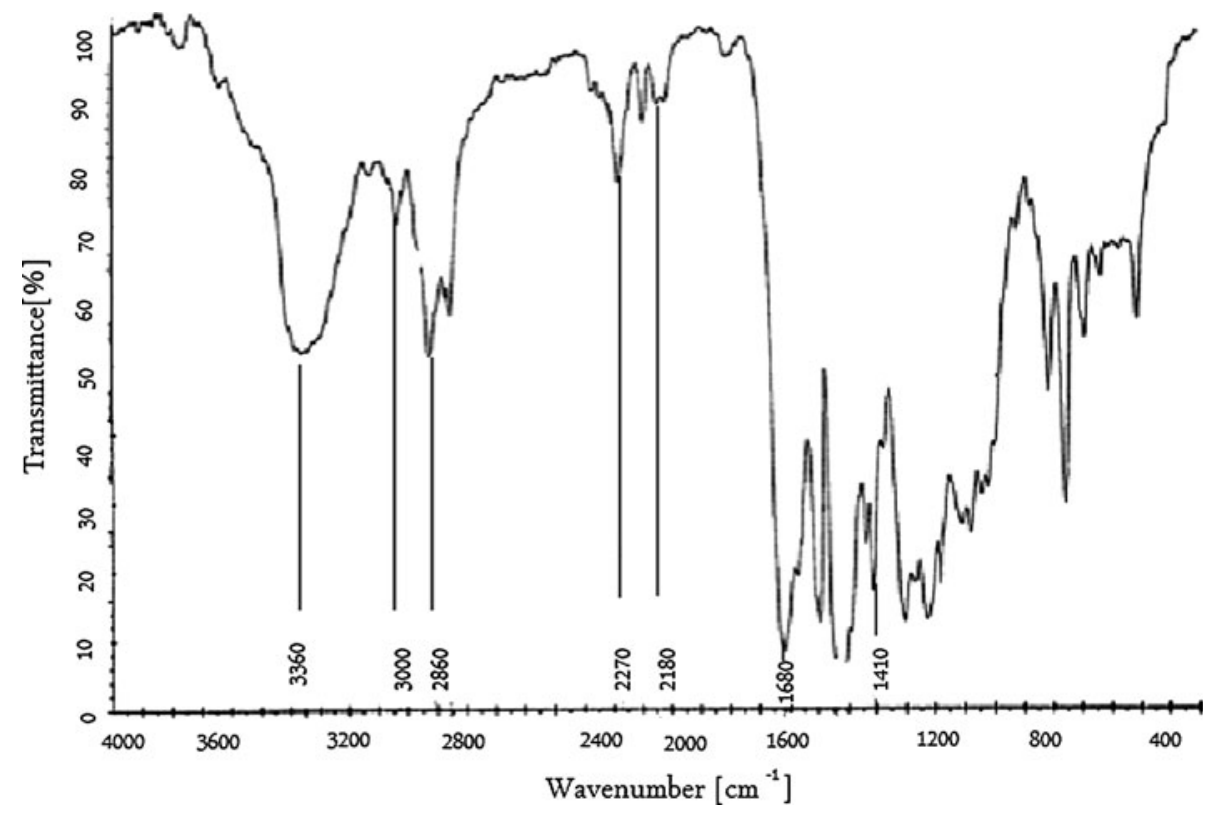

of foams prepared was below $5 \%$ in comparison with standard foam-(W0).

IR analysis confirmed presence of bands characteristic for isocyanurate $\left(1,710-1,690 \mathrm{~cm}^{-1}\right)$ and urethane (1,740-1,700 $\left.\mathrm{cm}^{-1}\right)$ bonds Fig. 7 .

Our studies proved waste wheat slops-often polluting environment - to be useful as the filler for preparation of rigid PUR-PIR foams. Foams characterized by the reduced brittleness, compressive strengths and content of closed cells, unchanged softening point and slightly increased absorbability of water in relation to standard foam were obtained in the case when they contained solid fraction of wheat slops in amount from 5 to $30 \% \mathrm{w} / \mathrm{w}$ in relation to the sum of polyol and polyisocyanate masses.

\section{Summary}

The results of our studies proved that the waste distillery slops could be successfully used as the fillers for rigid polyurethane-polyisocyanurate foams.

On account of the industrial application of rigid polyurethane foams, their brittleness is a very important property. The obtained foams were characterized by the considerably reduced brittleness $(16.9 \%$ for foam with $30 \%$ of filler) in comparison to standard foam (41.9\%) and it was achieved by increasing the content of solid fraction of wheat slops. Other properties of the foams were only slightly deteriorated in comparison to standard foam after introducing the filler into their composition.

Open Access This article is distributed under the terms of the Creative Commons Attribution Noncommercial License which permits any noncommercial use, distribution, and reproduction in any medium, provided the original author(s) and source are credited.

\section{References}

1. M. Ionescu, Chemistry and Technology of Polyols for Polyurethanes (Rapra Technology Limited, Shawbury, 2005)

2. A. Austin, Conference Papers, Utech, Maastricht, 2006

3. J. Paciorek-Sadowska, B. Czupryński, J. Liszkowska, Polimery 55, 1 (2010)

4. B. Czupryński, J. Paciorek-Sadowska, J. Liszkowska, J. Appl. Polym. Sci. 100, 3 (2006)

5. J. Paciorek-Sadowska J. Czupryński Appl. Polym. Sci. 102(6) (2006)

6. B. Czupryński, J. Liszkowska, J. Paciorek-Sadowska, J. Polym. Eng. 26, 6 (2006)

7. B. Czupryński, G. Kłosowski, K. Kotarska, J. Paciorek-Sadowska., Polimery 45, 6 (2000)

8. B. Czupryński, G. Kłosowski, K. Kotarska, H. Wolska, Przemysł Fermentacyjny i Owocowo-Warzywny 46, 1 (2002) 